doi: $10.18575 / \mathrm{msrs} . s m . e .17 .14$

UDC 616-089.5-7:615.212

COBISS.RS-ID 6831896

\title{
Incidence of Hypothension and Bradicards during the Spinal Aneshesion in Patients on Beta- Blockers Therapy
}

\begin{abstract}
Introduction: Spinal anesthesia (synonyms: subarachnoidal nerve block, subdural nerve block, subdural anesthesia, lumbar anesthesia, subarachnoid anesthesia) occurs by injection of local anesthetics within the subarachnoid space in the lumbal interspace. ${ }^{1}$ It is also called a neuroaxial blockade that represents the primary anesthetic technique in one-third of surgical procedures. ${ }^{2} \mathrm{~A}$ local anesthetic, given in this way, transits blocking the transmission of sensory, motor and autonomic nerve impulses transiently, resulting in the desired effects, sensory and motor blockade, as well as the side effects due to blocking autonomic nerve fibers, when unwanted effects of spinal anesthesia, hyopotension, bradycaria, nausea, vomiting and retention of urine occur. In this paper we examined the effect of spinal anesthesia on cardiovascular functions in patients whose sympathetic tonus is partly suppressed due to the chronic use of $\beta$-blockers due to essential hypertension. We wanted to know whether spinal anesthesia is a safe anesthetics technique in this group of patients or their effects are summed up, which would lead to cardiovascular instability that would result in greater use of pharmacological agents for the treatment of hypotension and bradycardia.
\end{abstract}

Aim of the Study: To examine cardiovascular stability during spinal anesthesia in patients on $\beta$-blocker therapy and determine the safety of its use in this group of patients.

Patients and Methods: After approval by the Ethics Committee of UCC Banja Luka, a prospective, observation study was conducted on 70 patients divided into two groups, aged 35-65 years, and it lasted from June 1st, 2013. until May 31st, 2016. Group N1, a working group, consisted of 35 patients who used beta-blocker, Metoprolol, in chronic therapy due to essential hypertension. The second group was a control group, N2, and it consisted of 35 healthy patients of the same age limit. Patients underwent spinal anesthesia for "bloodless" surgery on the inguines, perineum, urinary bladder, prostate, urethrae and lower extremities. No pregnant women, diabetic patients, kidney, liver and heart disease were involved in the work. Results: The results showed that there were a significantly higher number of patients with a critical drop in blood pressure, in the group of patients undergoing therapy with beta-blockers, $\geq 30 \%$, and alone with this more frequent use of vasopressor. Likewise, in the group of patients on beta-blocker therapy, significantly more patients developed bradycardia, i.e. a pulse of 50/min, which required the use of Atropine. Conclusion: Spinal anesthesia is not a safe anesthetic technique in patients on beta-blocking therapy

Key words: spinal anesthesia, beta-blockers, hypotension, bradycardia.

\section{Vera Gazdić ${ }^{1}$ Aleksandra Đorđević ${ }^{2}$, Milana Stanić, Dejan Nikicí, Darko Golić ${ }^{1}$}

${ }^{1}$ Clinic for Anesthesia and Intensive Care of UCC Banja Luka

${ }^{2}$ Department of Clinical Laboratory Diagnostics of UCC Banja Luka

\author{
Contact address: \\ Vera Gazdić \\ Street address: Zdrave Korde 1 \\ $780 o$ o Banja Luka, \\ Republic of Srpska \\ Bosnia and Herzegovina \\ e-mail: gazdic.vera@yahoo.com \\ phone number: +387-66-625-004
}

Submitted: May 11 ${ }^{\text {th }}, 2017$

Accepted: June 12 ${ }^{\text {th }}, 2017$ 


\section{Introduction}

Spinal anesthesia is one of the oldest, most useful and most commonly used techniques of regional anesthesia. ${ }^{1-3}$ By injecting local anesthetics into subarachnoidal space, a transient interruption of the implementation of nerve impulses in the spinal nerve roots and paralysis of autonomic, sensitive and motor nerve endings occurs.

Simpatectomy caused by spinal anesthesia leads to hemodynamic changes. The height of the block determines the enlargement of the sympathetic blockade that will determine the magnitude of the change in cardiovascular parameters. Hypertension and bradycardia are the most common adverse effects seen in sympathetic denervation. ${ }^{4}$ Hypotension occurs in about $33 \%$ in the nonopstetrics population. ${ }^{5}$ Arterial and venodilation occur in spinal anesthesia and together lead to hypotension. In patients with coronary artery disease, systemic vascular resistance may fall by $33 \%$ after spinal anesthesia. ${ }^{6}$ After spinal anesthesia, venodilation will be maximal, depending on the position of the vein in relation to the heart. If the veins lie below the right atrium, gravity will cause blood to accumulate on the periphery, and if the veins lie above the heart, the blood returns to the heart. The veins return blood to the heart and therefore the output depends on the patient's position during spinal anesthesia. ${ }^{7}$

Since cardiac output is determined by preload, the patient's position is an important factor because it determines preload, and therefore cardiac output. As long as the euvolemic patient is in a position with feet raised above the heart, there should be no significant changes in cardiac output after spinal anesthesia. The reversed Trendelenburg position, however, leads to a significant drop in preload and thus significantly reduces cardiac output. 8,9

Sympathetic cardioaccelerative fibers range from Th1 to Th4 spinal segment, and the blocking of these fibers is considered a cause of bradycardia. A fall in venous return may also cause bradycardia due to a fall in filling pressure which triggers cardiac stretching receptors to slow down the cardiac action. Although both of these mechanisms have been taken as the cause of bradycardia, others, still unspecified factors can be considered as its cause. ${ }^{10}$ Benzold-Jarish's reflex is considered to be the direction of bradycardia, hypotension, and cardiovascular collapse after central neuroaxial anesthesia, especially in spinal anesthesia. $^{11,12}$

Even when bradycardia is well tolerated, asistolia, the second and third degree of the cardiac block can occur, so it should always be cautious when monitoring the patient after spinal anesthesia and should be reacted quickly and aggressively. ${ }^{13}$

The basis of the therapy of hypotension in spinal anesthesia is the treatment of the cause that has been brought to her. The cardiac output and venous return should be resolved, using the bolus of crystalloid to increase the volume of the vein. Prehydration with 500 to $1500 \mathrm{ml}$ of crystalloid has been shown to be useful in reducing the occurrence of hypotension (in some studies, but in some no). ${ }^{14-16}$

Treatment of hypotension remains essential for myocardial and brain perfusion. If the patient has no symptoms, it is considered that the pressure drop to $33 \%$ should not be treated. ${ }^{17,18}$ For pharmacological treatment of hypotension, vasopressors remain the basis of treatment. The combination of $\alpha$ and $\beta$ agonists is better than the use of pure $\alpha$-agonists, so that Ephedrine is the drug of choice. ${ }^{19,20}$ Cardiac output and peripheral vascular resistance grow with ephedrine, which improves blood pressure. However, the physiological treatment of hypotension causes the focus to be restored.

\section{Aim of the Study}

The aim of this paper is to examine cardiovascular stability during spinal anesthesia in patients on $\beta$-blocker therapy and to determine the safety of its use in this group of patients.

\section{Patients and Methods}

The research had the characteristic of a prospective, observational study, carried out after the approval by the Ethics Committee of UCC Banja Luka, at the surgical clinics of this institution in the period from June 1st, 2013 until May 31st, 2016. The study included 70 patients, divided into two groups of 35 patients who underwent spinal anesthesia for surgery on inguinum, urinary bladder, prostate, urethra and lower extremities. N1 was a work group, ASA II status patients taking beta-blockers (Metoprolol) in chronic therapy due to essential hypertension, longer than 6 months (mean $10.5 \mathrm{msc}$ ). In another, the N2 group-control group were ASA I status patients, healthy patients who did not take antihypertensive therapy. The age limit was 35-65 years. The hypotension that required pharmacological therapy with vasopressor (in our case Effortil-Etilefrin) implied an arterial pressure drop of $\geq 30 \%$. Severe bradycardia was defined $\leq 50 \mathrm{~min}$ and required the administration of Atropine. Intraoperative bleeding was no greater than $250 \mathrm{ml}$.

Inclusion criteria were: all patients in whom spinal anesthesia could be performed for lower abdominal 
surgery, urological operations and surgeries at the lower extremities. Patients with essential hypertension belonged to ASA II score. In the working group, patients taking Metoprolol in chronic treatment for essential hypertension at a dose of $100 \mathrm{mg}$ divided into 1-2 $\mathrm{X}$ per day and for a duration longer than 6 months (the therapeutic average was $10.5 \mathrm{msc}$ ). On the day of surgery, they took $50 \mathrm{mg}$ Metoprolol in the morning. Value of BMI were 18-30, aged 35-65 years, blood pressure measured in the anesthetic clinic did not exceed 160/90 mmHg.

Exclusion criteria were: absolutely contraindicated spinal block, patient's refusal to perform spinal anesthesia, renal and cardiac insufficiency, arrhythmias as np. atrial fibrillation, supraventricular tachycardia, AV blocks, block of the left branch of Hiss's bundle, diabetes, blood loss during surgery of more than $250 \mathrm{ml}$, pregnant women, patients under 35 years of age and older than 65 years, a preoperative break with th $\beta$-blockers. $30 \leq \mathrm{BMI}$ $\leq 20$, blood pressure measured in the anesthesiology clinic higher than 160/90 $\mathrm{mmHg}$.

Upon arrival at the operating room, patients were given non-invasive hemodynamic monitoring (ECG-II, TA, pulse) and respiratory monitoring (pulse oximetry for the determination of satO2).

Upon arrival at the operating table, i.v. lines and both groups performed a pre-treatment with $500 \mathrm{ml}$ of $0.9 \% \mathrm{NaCl}$ in bolus for $15 \mathrm{~min}$. Patients of both groups were premedicated on the operating table with 1-3 mg Flormidal i.v. And 50 mcg of Fentanyl i.v.

In this study, we carried out a block at the L3-L4, L4L5 level in a sitting position, a medial approach, and immediately afterwards the patient was put in a supine to a leveled table. There was no movement of the patient $15 \mathrm{~min}$. in the anesthetic fixation phase. For the spinal block, a local anesthetic of $0.5 \%$ Buoivacaine, isobaric, at a dose of $3 \mathrm{ml}$ and $15 \mathrm{mg}$ was used, which provided sufficient analgesia for the intended surgery. We used spinal needles-Quincke 25-27 G, Brown. We examined the height of the block based on the perception of warmcold feeling and did not sublime above Th7. During the operation, the patient received oxygen via an oxygen mask of $5 \mathrm{~L} / \mathrm{min}$. Intraoperative liquid was compensated by crystalloids, $0.9 \% \mathrm{NaCl}, 15 \mathrm{ml} / \mathrm{kg} / \mathrm{h}$.

Arterial pressure drop of $30 \%$ or more in relation to measurement $15 \mathrm{~min}$. before giving spinal anesthesia (initial value) was considered significant and indicated the use of vasopressor, Etilefrin-Effortil i.v. in a dose of 5-10 mg. Bradycardia, HR $\leq 50 / \mathrm{min}$ indicated the administration of Atropine $0.5 \mathrm{mg}$ i.v.
The electrocardiogram (rhythm, frequency) was monitored continuously, the second drain, through the MEDIA YG 6000 monitoring device. Three types of surgery were performed: surgery on the lower extremities, inguinum and urological operations.

Figure 1. Position of the Patient for Performing Spinal Anesthesia and Level of Puncture

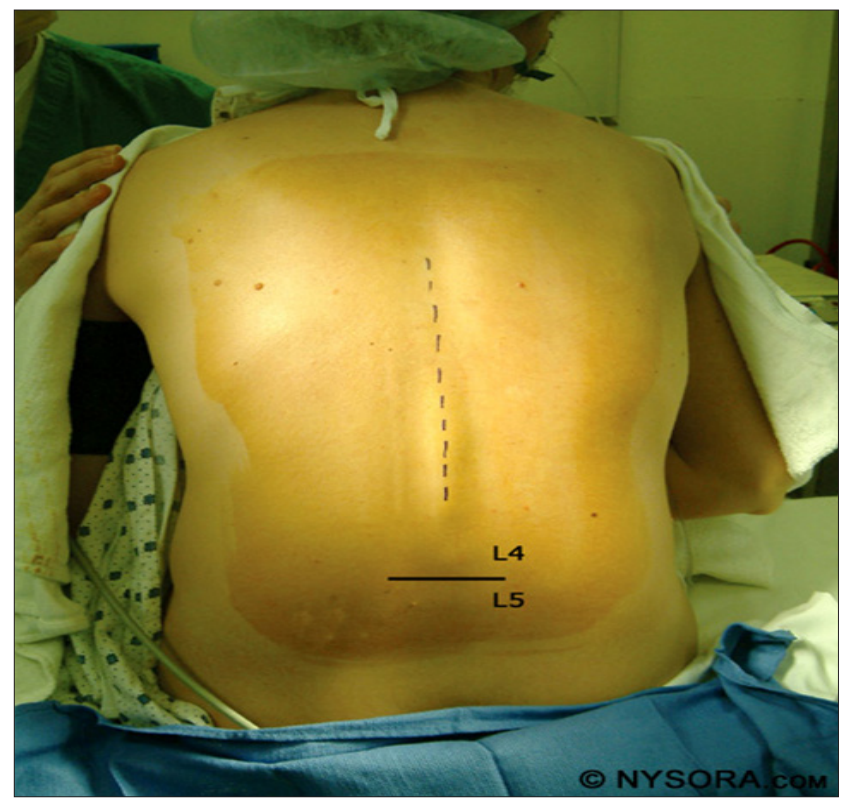

\section{Results}

The results showed that in the control group in which patients did not take beta-blockers, in 34 patients there was no significant drop in blood pressure ( $\geq 30 \%)$ and did not administer Effortil, which made $97.1 \%$ of the total number of patients, while it was given to one (1) patient, which made $2.9 \%$ of the total number of patients $(\mathrm{N} 2=$ 35).

Graph 1. Graphical Presentation of the Percentage Distribution of Effortil by Group

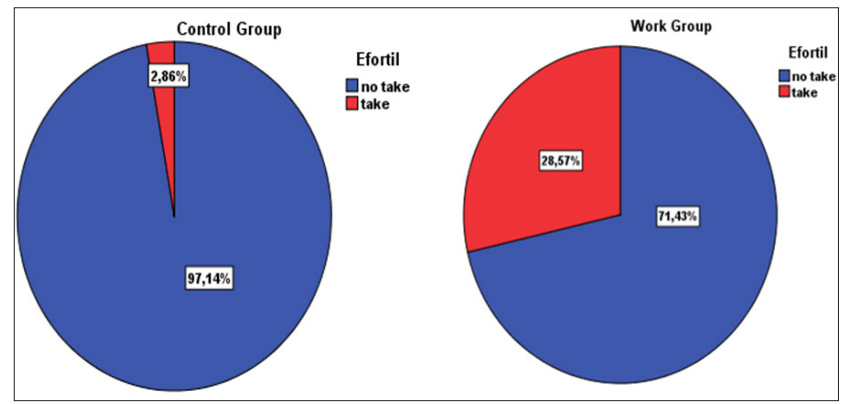

In the work group, where the patients were treated with beta-blockers, in 25 patients there was no drop in blood 
pressure for more than $30 \%$ and no Efortil administered, which made $71.4 \%$ of the total number of patients in the work group $(\mathrm{N} 1=35)$. In 10 patients, there was a fall in blood pressure $\geq 30 \%$ indicating the use of Efortil, which made $28.6 \%$ of the total number of patients.

The Hi-square independence test revealed a significant difference between the working and control group in the proportion of patients receiving efortil and patients who did not receive it $(\chi 2(\mathrm{df}=1, \mathrm{~N}=70)=8.737, \mathrm{p}=0.003 ; \mathrm{p}$ $<0.05)$. Between the Effortil and the beta-blocker, there was a midrange connection, $\mathrm{fi}=0.353$.

When it comes to bradycardia requiring Atropine ( $\mathrm{HR} \leq 50$ / $\mathrm{min})$, in the control group where patients did not take beta-blockers, 32 patients did not develop bradycardia of $\leq 50 / \mathrm{min}$ intraoperatively and they did not receive Atropine, which made $91.4 \%$ of the total number of patients N2 $=35$ control groups. 3 patients received Atropine, which accounted for $8.6 \%$ of the total number of control group patients.

In the working group, in which patients took betablockers, we had 25 patients who had not received Atropine, which made $71.4 \%$ of the total number of patients $\mathrm{N} 1=35$ working groups and 10 patients receiving Atropine, which made $28.6 \%$ of the total number of patients.

Graph 2. Graphic Representation of Percentage Use of Atropine

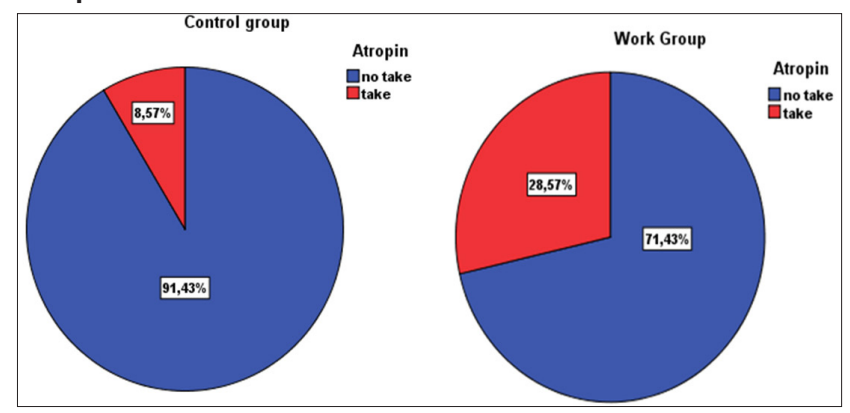

The Hi-square independence test revealed a significant difference between the working and control group in the proportion of patients receiving atropine and patients who did not receive it $\left(\mathrm{X}^{2}(\mathrm{df}=1, \mathrm{~N}=70)=4.629, \mathrm{p}=0.031\right.$; $\mathrm{p}<0,05)$. There was a medium-intensity connection, $\mathrm{fi}=$ 0.257 between the atropine and the bet-blocker.

\section{Discussion}

Numerous authors examined the incidence of side effects of spinal anesthesia and factors contributing to their emergence. Carpenter et al. had an incidence of hypotension of $33 \%$ and bradycardia of $13 \% .{ }^{5}$ They reported that spinal anesthesia above $\mathrm{Th} 5$ levels, age $\geq 4 \mathrm{O}$ years, basal systolic blood pressure $<120 \mathrm{mmHg}$, spinal puncture above L2-L3 interspace, combination of general and spinal anesthesia, and addition of Phenilefryne to local anesthetic, are variables that contribute to the development of hypotension during spinal anesthesia. The basal pulse rate was lower than $60 / \mathrm{min}$, ASA I status, $\beta$-blocker therapy, and level of spinal anesthesia higher than $\mathrm{Th}_{5}$ were reported as risk factors for the development of bradycardia during spinal anesthesia.

Dinesh Singla et al. had a goal to investigate risk factors that predict the occurrence of early hypotension in spinal anesthesia. ${ }^{21}$ The work was carried out on a group of 1000 patients, for the purpose of early prophylaxis and timely therapeutic intervention to reduce the morbidity and mortality associated with this type of anesthesia. They defined hypotension as a fall of art. blood pressure below $80 \%$ of basal (preanesthetic) or systolic pressure drop of $90 \mathrm{mmHg}$ and lower after the block is performed. Dinesh S. and others found that the age over 50 years, female $\mathrm{BMI}>30 \mathrm{~kg} / \mathrm{m} 2$, hypertension in the history of the disease increases the risk of developing hypotension during spinal anesthesia. Antihypertensive therapy reduces the risk of hypotension. The following risk factors for the emergence of early hypotension in spinal anesthesia are the history of diabetes mellitus in the anamnesis and anemia. In our work, the existence of diabetes mellitus and anemia were the criteria for exclusion from the study. The following risk factors for developing early hypotension after performing spinal anesthesia were basal heart rate, systolic and diastolic blood pressure, and pulse pressure. They found that basal (preanesthetic) systolic blood pressure $>135 \mathrm{mmHg}$ increased the risk of early hypotension after performing spinal anesthesia. In our work, in the work group, only 4 patients had basal systolic blood pressure lower than $135 \mathrm{mmHg}$ (11.4\%) and did not develop hypotension after performing spinal anesthesia. 31 patients had a value above $135 \mathrm{mmHg}$ (88\%). Of them, 19 (54\%) developed hypotension after the block was performed, and all who developed had a pre-systolic systolic pressure of $>135 \mathrm{mmHg}$. In the control group in our work, 5 patients (14\%) developed hypotension. 4 of them had basal systolic pressure above $135 \mathrm{mmHg}$, and only one patient had basal systolic pressure below this value.

P. Kaimar, N. Sanjin and others included 90 patients divided into three groups of 30 patients, compared the formation of hypotension and bradycardia between the three groups. ${ }^{22}$ The first group, group C, consisted of 30 patients who received Ca-blockers in their therapy for essential hypertension. The second group consisted of 30 patients on beta-blocking therapy, group B, and for the same indication. The third group was a control group, group $\mathrm{N}$, and it consisted of 30 patients who did not use 
therapy, ASA and status. Statistical analysis found that the incidence of hypotension was not significant when compared to these three groups. However, the frequency of administration of Mephenteramine was significantly higher in the Ca-blocker group compared with the control group ( $\mathrm{p}<0.05)$. In our work, in the group receiving betablockers, 19 patients (54\%) developed hypotension, a decrease in systolic pressure by $20 \%$ and more, which was not significantly different from the values that Kaimar and Sanjin obtained in their work. In our control group, 5 patients (14\%) had a systolic pressure drop of $20 \%$ or more, which was significantly less than the value of 50\% of control group patients in Kaimar and Sanji. However, in patients on beta- blockers, $30 \%$ of patients developed bradycardia. This figure does not differ significantly from our work, because in our work, about $30 \%$ of patients (more precisely $28.57 \%$ ) developed bradycardia on the chronic beta blockade.

Lee JH, Naum Da Joeng and Park Jungho defined bradycardia as a heart rate of $<50 / \mathrm{min}$ for one minute. ${ }^{23}$ Ten variables were identified as the risk factor for its formation: sex, age, BMI, spinal anesthetic dose, sensor blockade level, basal heart rate, baseline systolic blood pressure, basal value of diastolic blood pressure, basal value of mean blood pressure and diabetes mellitus in the history of the disease. Statistical analysis was performed to determine the correlation between bradycardia and these 10 variables. The following data were obtained: $13.4 \%$ of patients developed bradycardia. No episodes of asystole was shown. B-blockers, slowing down the heart rate, might have been a risk factor for the development of bradycardia during spinal anesthesia. They came to the conclusion that male sex, absence of diabetes and low basal heart rate, factors associated with statistically significant incidence of bradycardia during spinal anesthesia.

In our work, 10 patients (28.5\%) in the working group developed bradycardia, HR $\leq 50 / \mathrm{min}, 7$ men and 3 women. In the control group, 3 patients (8.5\%) reported bradycardia and were all male. Statistical analysis showed that this difference was significant. No patient in our study in whom bradycardia was recorded after performing spinal anesthesia, both in the work and in the control group did not have a heart rate lower than 40/ min. Diabetes mellitus in the history of the disease was the exclusion criterion in our study.

\section{Conclusion}

Based on all the above mentioned, it follows that in patients on $\beta$-blocker therapy, there is a significantly greater decrease in arterial pressure during spinal anesthesia, and that there is a greater use of pharmacological agents for resolving hypotension and bradycardia. Based on all of the above, we can conclude that spinal anesthesia is not a safe anesthetic technique in patients on betablocking therapy.

\section{Reference}

1. Marko Jukić et all. Subarahnoidalna anestezija.Kliniĉka anesteziologija 2005;43: 558

2. Michael Zaugg, Lukas Bestmann, Jochanes Wacker et all. Adrenergic Receptor Genotip but Not Perioperative Bisoprolol Therapy May Determine Cardiovascular Outcame in At-risk Patients Undergoing Surgey with Spinal Block. Anaesthesiology 2007; 33-44

3. Danilo Janković. Regionalna nervna blokada i infiltraciona terapija bola 2004; 272

4. Bigler D, Hjortso NC, Edstrom H, et al. Comparative effects of intrathecal bupivacaine and tetracaine on analgesia, cardiovascular function and plasma catecholamines. Acta Anaesthesiol Scand 1986;30:199-203. https://doi.org/10.1111/j.1399-6576.1986.tbo2396.x PMid:3755561

5. Carpenter RL, Caplan RA, Brown DL, et al. Incidence and risk factors for side effects of spinal anesthesia. Anesthesiology 1992;76:906-16.

https://doi.org/10.1097/00000542-199206000-00006 PMid:1599111

6. Rooke GA, Freund PR, Jacobson AF. Hemodynamic response and change in organ blood volume during spinal anesthesia in elderly men with cardiac disease. Anesth Analg 1997;85:99-105.

https://doi.org/10.1097/00000539-199707000-00018 https://doi.org/10.1213/00000539-199707000-00018 PMid:9212130

7. Shimosato S, Etsten BE. The role of the venous system in cardiocirculatory dynamics during spinal and epidural anesthesia in man. Anesthesiology 1969;30:619-28. https://doi.org/10.1097/00000542-196906000-00009 PMid:5787172

8. Anzai Y,NishikawaT. Heart rate responses to body tilt during spinal anesthesia. Anesth Analg 1991;73:385-90. https://doi.org/10.1213/ooooo539-199110000-00002 PMid:1897764

9. Bergenwald L,FreyschussU,KaijserL, et al. Cardiovascular response to spinal anaesthesia in elderly men: Effects of head-up tilt and dihydroergotamine administration. Clin Physiol 1981;1:453-60.

https://doi.org/10.1111/j.1475-097X.1981.tboo912.x PMid:7199992

10. Caplan RA, Ward RJ, Posner K, et al. Unexpected cardiac arrest during spinal anesthesia: A closed claims analysis of predisposing factors. Anesthesiology 1988;68:5-11. https://doi.org/10.1097/00000542-198801000-00003 https://doi.org/10.1097/00000542-198806000-00042 PMid:3337390 
11. Ou CH, Tsou MY, Ting CK, et al. Occurrence of the Bezold-Jarisch reflex during Cesarean section under spinal anesthesia-a case report. Acta Anaesthesiol Taiwan 2004;42:175-8. PMid:15551897

12. Mackey DC, Carpenter RL, Thompson GE, et al. Bradycardia and asystole during spinal anesthesia: A report of three cases without morbidity. Anesthesiology 1989;70:866-8. https://doi.org/10.1097/00000542-198905000-00026 PMid:2655502

13. Bernards CM, Hymas NJ. Progression of first degree heart block to high-grade second degree block during spinal anaesthesia. Can J Anaesth 1992;39:173-5. https://doi.org/10.1007/BFo3008651 PMid:1544200

14. Graves CL,Underwood PS, Klein RL, et al. Intravenous fluid administration as therapy for hypotension secondary to spinal anesthesia. Anesth Analg 1968;47:548-56. https://doi.org/10.1213/00000539-196809000-00018 PMid:5691695

15. Venn PJ, Simpson DA, Rubin AP, et al. Effect of fluid preloading on cardiovascular variables after spinal anaesthesia with glucose-free $0.75 \%$ bupivacaine. $\mathrm{Br} \mathrm{J}$ Anaesth 1989;63:682-7.

https://doi.org/10.1093/bja/63.6.682

PMid:2611069

16. Coe AJ, Revanas B. Is crystalloid preloading useful in spinal anaesthesia in the elderly? Anaesthesia 1990;45:241-3. https://doi.org/10.1111/j.1365-2044.1990.tb14696.x PMid:2334037

17. Ronald D. Miller, MD.Spinal, epidural,and cudal anaesthesia. Miller's Anesthesia 2005;43:1658-60.

18. Mackey DC. Phisiological effects of regional block. In Brown DL(ed). Regional anaesthesia et analgesi 1996. Philadelphia ,WB Saunders; pp 397-422.

19. Butterworth JF 4th, PiccioneWJr, Berrizbeitia LD, et al. Augmentation of venous return by adrenergic agonists during spinal anesthesia. Anesth Analg 1986;65:612-6. https://doi.org/10.1213/00000539-198606000-00009 PMid:2871774

20. Ward RJ, Kennedy WF, Bonica JJ, et al. Experimental evaluation of atropine and vasopressors for the treatment of hypotension of high subarachnoid anesthesia. Anesth Analg 1966;45:621-9.. PMid:5950381

21. D. Singla, Suneet Kathuria, Avtar Singh, Tej, at al. Risk factors for development of early hypotension during spinal anaesthesia.Journal of Anaesthesiology Clinical Pharmacology 2006; 22(4):387-93.

22. P. Kaimar, N. Sanji, M. Upadya, K.R. Mohammed. A comparasion of hypotension and bradycardia following spinal anesthesia in patiens on calcium channel blockers and $\beta$-blockers. Indian J. Pharmacol 2012 Mar-Apr; 44(2): 193-6.

https://doi.org/10.4103/o253-7613.93847 PMid:22529474 PMCid:PMC3326911

23. Lee JH, Nam Da Jeong, Park Jungho. Incidence and Risk Factors of Severe Bradycardia During Spinal Anesthesia with Chronic $\beta$-Blockade. International Journal of Anesthesiology and Resarch 2015; 3(4): 105-8. 


\section{Incidenca hipotenzije i bradikardije tokom spinalne anestezije kod pacijenata na terapiji beta- blokatorima}

\section{SAŽETAK}

Uvod: Spinalna anestezija (sinonimi: subarahnoidalni nervni blok, subduralni nervni blok,subduralna anestezija, lumbalna anestezija, subarahnoidalna anestezija) nastaje uštricavanjem lokalnog anestetika unutar subarahnoidalnog prostora u lumbalnom interprostoru. ${ }^{1}$ Zove se još i neuroaksijalna blokada koja predstavlja primarnu anesteziološku tehniku kod jedne trećine hirurških procedura. ${ }^{2}$ Lokalni anestetik, dat na ovaj način, tranzitorno blokira prenos senzornih, motornih i autonomnih nervnih impulsa, a rezultat toga je nastanak nama željenih efekata, senzorne i motorne blokada, ali i nuspojave uslijed blokiranja autonomnih nervnih vlakana, kada nastaju neželjeni efekti spinalne anestezije, hipotenzija, bradikardija, mučnina, povraćanje i retencija urina. $\cup$ ovom radu smo ispitivali kakav efekat će spinalna anestezija imati na kardiovaskularnu funkciju kod pacijenata čiji je simpatički tonus dijelom suprimiran uslijed hronične upotrebe $\beta$-blokatora zbog esencijalne hipertenzije. Interesovalo nas je da li je spinalna anestezija sigurna anesteziološka tehnika kod ove grupe pacijenata ili se njihova dejstva adiraju što bi dovelo do kardiovaskularne nestabilnosti koja bi rezultirala većom upotrebom farmakoloških agenasa za tretiranje hipotenzije i bradikardije.

Cilj rada: Ispitati kardiovaskularnu stabilnost tokom spinalne anestezije kod pacijenata na terapiji $\beta$-blokatorima i utvrditi sigurnost njene primjene kod ove grupe pacijenata.

Ispitanici i metode: Nakon odobrenja od strane Etičkog odbora UKC Banjaluka, sprovedena je prospektivna, opservaciona studija koja je trajala od 01.06.2013. do 31.05.2016. godine na 70 pacijenata podijeljenih u dve grupe, starosne dobi od 3565 godina. Grupu N1, radna grupa, sačinjava 35 pacijenata koji zbog esencijalne hipertenzije upotrebljavaju beta-blokator, metoprolol, u hroničnoj terapiji. Druga grupa je kontrolna grupa, N2, i nju čini 35 zdravih pacijenata iste dobne granice. Pacijenti su podvrgnuti spinalnoj anesteziji za „beskrvne“ operacije na igvinumu, perineumu, mokraćnoj bešici, prostati, uretri i donjim ekstremitetima. U rad nisu bile uključene trudnice, te pacijenti sa dijabetesom, bubrežnim, jetrenim i srčanim obolenjima.

Rezultati: Rezultati pokazuju da je u grupi pacijenata koja je pod terapijom beta-blokatorima značajno veći broj pacijenata sa kritičnim padom krvnog pritiska, $\geq 30 \%$ i samim tim češćom upotrebom vazopresora. Isto tako, u grupi pacijenata na terapiji beta-blokatorima značajno je više pacijenata razvilo bradikardiju, tj. puls $\leq 50 / \mathrm{min}$, koja je zahtevala upotrebu atropina.

Zaključak: Spinalna anestezija nije sigurna anesteziološka tehnika kod pacijenata na terapiji beta-blokatorima.

Ključne riječi: spinalna anestezija, beta-blokatori, hipotenzija, bradikardija. 